\title{
УДК 616.12-008.331.1-057.874:57.034"34" \\ BLOOD PRESSURE IN SCHOOL AGE CHILDREN DEPENDING ON CIRCADIAN RHYTHMS
}

\author{
D. Yu. Nechytailo, Yu. N. Nechytailo, N. I. Kovtyuk \\ Bukovinian State Medical University, Ukraine \\ Department of pediatrics, neonatology and perinatal medicine, Chernivtsi, Ukraine
}

\begin{abstract}
Objective: to assess the 24 hours fluctuations of blood pressure in school age children by ambulatory blood pressure monitoring

Material and methods. 45 children of school age were examined. Daily blood pressure monitoring was performed in the hospital using the device Ambulatory Blood Pressure Monitor Holter ABPM50.

Results. Among the surveyed children normal circadian index had only two patients (1.28 and 1.32 i.u.). The remaining patients had rigid circadian rate (less than 1.2 i.u.), which may indicate the presence of vegetopathology and violation of both afferent and efferent chains of vagosympatic regulation of heart rate, the phenomenon of «denervated» heart
\end{abstract}

Key words: school age children, ambulatory blood pressure monitoring.

\section{АРТЕРИАЛЬНОЕ ДАВЛЕНИЕ У ДЕТЕЙ ШКОЛЬНОГО ВОЗРАСТА В ЗАВИСИМОСТИ ОТ СУТОЧНОГО РИТМА}

\author{
Д. Ю. Нечитайло, Ю. Н. Нечитайло, Н. И. Ковцук
}

Буковинский государственный медицинский университет, Украина

Кафедра педиатрии, неонатологии и перинатальной медицины, Чернивцы, Украина

Цель: оценить суточное колебание артериального давления у детей школьного возраста с помощью суточного мониторирования артериального давления

Maтериалы и методы. Были обследованы 45 детей школьного возраста. Суточный мониторинг артериального давления проводили в больнице с помощью устройства «Амбулаторный монитор артериального давления - АВРМ50».

Pезультаты. Среди обследованных детей нормальный циркадный индекс имели только 2 пациента (1,28 и 1,32 ME). Остальные пациенты имели ригидный циркадный ритм (менее $1,2 \mathrm{ME})$, что может свидетельствовать о наличии вегетопатологии и нарушении как афферентных, так и эфферентных цепей вегетативной регуляции сердечного ритма, так называемый феномен «денервированного» сердца.

Ключевые слова: дети школьного возраста, суточный мониторинг артериального давления.

\section{Introduction}

The high blood pressure (BP) is the leading risk factor - related cause of death throughout the world, accounting for $12.8 \%$ of all deaths, including $51 \%$ of stroke deaths and $45 \%$ of coronary heart disease deaths [1]. The prevalence of hypertension in youths is also on the rise. In fact, the entire distribution of childhood BP has shifted upward in the world by $1.4 \mathrm{~mm} \mathrm{Hg}$ for systolic BP (SBP) and $3.3 \mathrm{~mm} \mathrm{Hg}$ for diastolic BP (DBP) [2]. A crosssectional pediatric study conducted in Canada found that obese adolescents had $7.6 \mathrm{~mm} \mathrm{Hg}$ higher SBP than normal-weight youths, with BMI exerting the strongest effect on BP $[3,4]$.

High blood pressure in children is over 95percentile distribution curve of BP in the population for that age, gender and height. Blood pressure between 90-th percentile and 95-th percentile is high but steel interpreted as normal. For better diagnosis of hypertension in children is using 24 hour ambulatory blood pressure monitoring (ABPM) $[5,6]$.
It has been suggested that the current reliance on clinic blood pressure alone might result in substantial overdiagnosis of hypertension; ambulatory monitoring might allow for more appropriate targeting of patients most likely to benefit from lifelong drug treatment. In fact, some recent guidelines mandate confirmation of elevated office blood pressures by measuring blood pressure at home or by 24 hour ABPM to make a diagnosis of hypertension. This area is of particular interest to nephrologists, given the high prevalence of hypertension in children with chronic kidney disease, and the critical role of blood pressure control in slowing decline in kidney function and reducing risk of cardiovascular disease.

\section{The aim}

To assess the 24 hours fluctuations of blood pressure in school age children by ambulatory blood pressure monitoring.

\section{Materials and methods}

There were 45 healthy children of school age included investigation. Their average age was 14,2 \pm 
0,21 years. We used the following methods: clinical, anthropometric, laboratory and screening for elevated blood pressure. The covariates included age, sex, BMI and other. The children with elevated BP conducted 24 hours ambulatory blood pressure monitoring.

The blood pressure monitoring was performed in the hospital using the device Ambulatory Blood Pressure Monitor Holter ABPM50 with the cuff, the size of which was selected according to age and arm circumference of children. Registration of blood pressure and heart rate was carried out in the phase of compression by oscillometric method. The interval between measurements during the day was 30 minutes, during the night rest -2 hours. We had observed the main blood pressure indexes: systolic blood pressure (SBP), diastolic blood pressure (DBP), average arterial pressure (AP av), heart rate (HR) and pulse arterial pressure (PAP). The received results were analyzed and calculated in statistical tool - «Statistica», 6.1 .

\section{Received results}

Most of the children did not show any complaints. A group of children for the survey was selected on the basis of the establishment of elevated blood pressure during routine inspection and / or detect excessive body mass index (BMI) [7, 8]. Only one third of children complained on periodical headaches, pain in the heart, significant psycho-emotional and physical stress reactions.

Table 1 - Anthropometric indexes of children

\begin{tabular}{|l|c|c|}
\hline \multirow{2}{*}{ Index } & \multicolumn{2}{|c|}{ Group of exanimate children $(\mathrm{n}=45)$} \\
\cline { 2 - 3 } & $\mathrm{BMI}<24,9 \mathrm{~kg} / \mathrm{m}^{2}(\mathrm{n}=32)$ & $\mathrm{BMI}>24,9 \mathrm{~kg} / \mathrm{m}^{2}(\mathrm{n}=13)$ \\
\hline Height, $\mathrm{cm}$ & $172,7 \pm 0,03$ & $178,0 \pm 0,01^{*}$ \\
\hline Weight, $\mathrm{kg}$ & $65,5 \pm 3,4$ & $93,0 \pm 4,4^{*}$ \\
\hline BMI, $\mathrm{kg} / \mathrm{m}^{2}$ & $21,9 \pm 0,8$ & $29,4 \pm 1,3^{*}$ \\
\hline
\end{tabular}

$* \mathrm{p}<0,05$.

In surveyed children the average SBP level was $115,5 \pm 3,7 \mathrm{~mm} \mathrm{Hg}$, average night level of $\mathrm{SBP}-105,9 \pm 4,3 \mathrm{~mm} \mathrm{Hg}$. The average daily level of diastolic blood pressure DBP was $63,4 \pm$ $2,7 \mathrm{~mm} \mathrm{Hg}$, average night DBP level $-54,8 \pm$ 2,7 $\mathrm{mm} \mathrm{Hg}$.

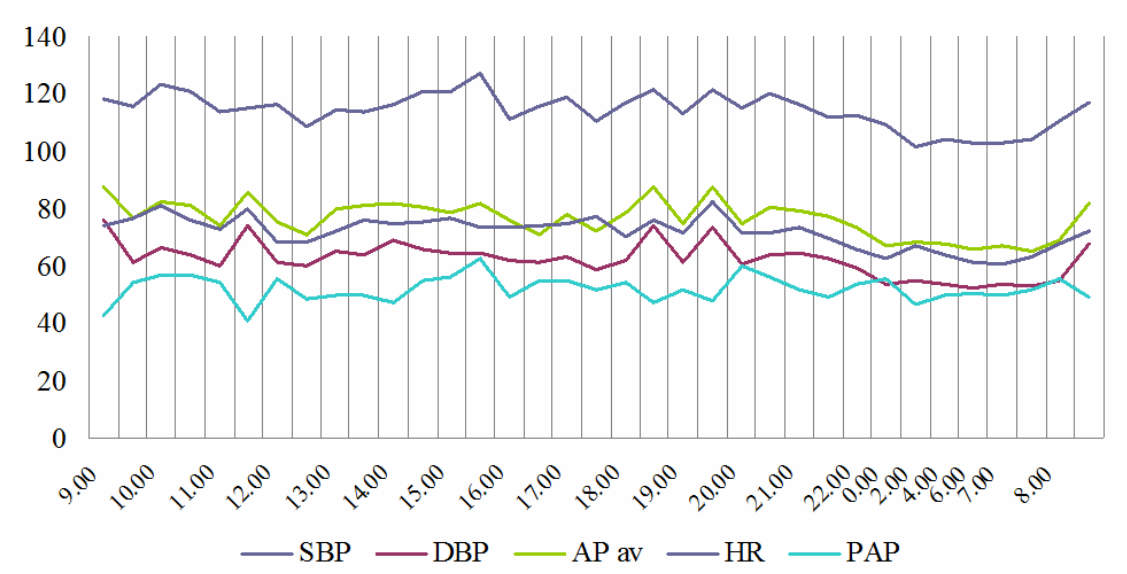

Figure 1 - The main blood pressure indexes in surveyed children

Normally circadian value index is $1,24-1,44$ units, indicating a stable organization of vegetative circadian rhythm of the heart. Among the children surveyed normal circadian index had only two patients (1.28 and 1.32). The remaining patients had rigid circadian rate (less than 1.2), which may indicate the presence of vegetopathology in violation of both afferent and efferent chains so vagosympatic regulation of heart rate, the phenomenon of «denervated» heart.

Based on the results of the analysis and comparison of average levels of daily and nightly average level of BP the group of patients (12 children) with normal night decrease (dippers) of both systolic and diastolic BP, which daily index was in the range $10-20 \%$ was selected.

Children with insufficient nocturnal decline of blood pressure (circadian index less than $10 \%$ ), non-dippers, was 21,8 of them had a daily index of less than $10 \%$ of both SBP and DBP, in three children there was insufficient reduction at night only of SBP, while DBP reduction was between 10-20\%.

7 patients were assigned to a group of over-dippers (excessive blood pressure lowering night, more than $20.0 \%$ ) which was registered only at night DBP reduction of over $20 \%$ compared to daytime performance and reduce nightly average SBP compared to the average SBP was within normal limits. 


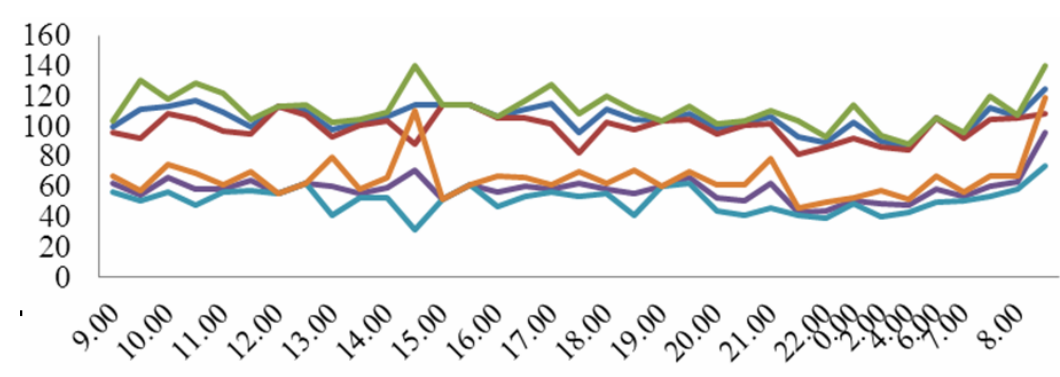

$-\mathrm{SBP}$ av $-\mathrm{SBP} \min \longrightarrow \mathrm{SBPmax} \longrightarrow \mathrm{DBP}$ av $-\mathrm{DBP} \min -\mathrm{DBP} \max$

Figure 2 - Dippers

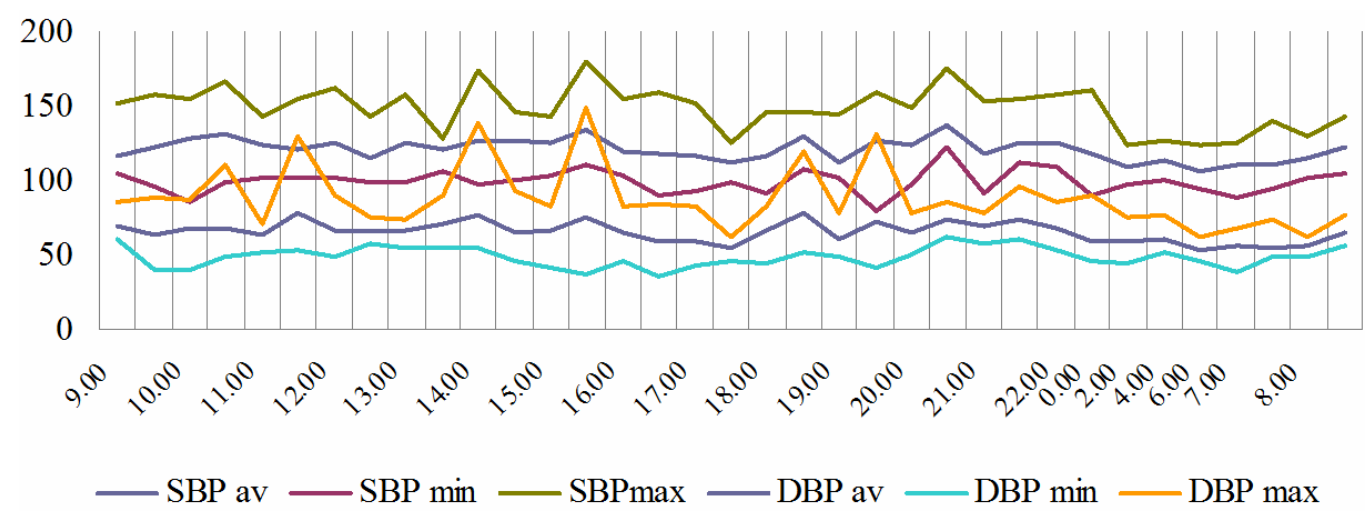

Figure 3 - Non-dippers

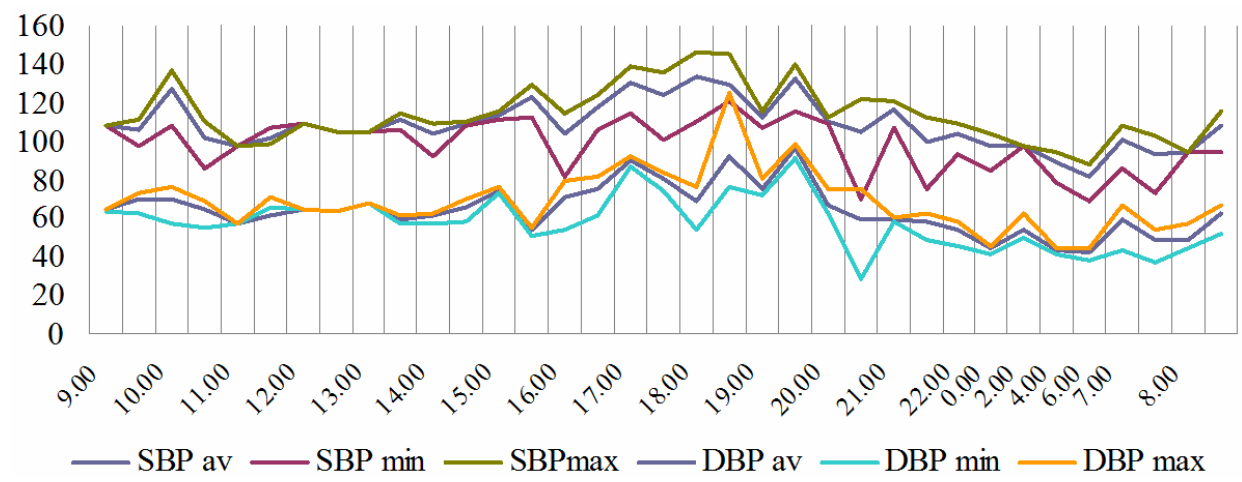

Figure 4 - Over-dippers

One boy was assigned to a group of nightpeakers because he was registered nightly average DBP increase of $11.5 \%$ compared to the average dates.

At the same time we found a connection between high BMI (over 95-th percentile) and high level of blood pressure, especially of SBP. In 9 children with high BMI we marked that the level of SBP was higher than $140 \mathrm{~mm} \mathrm{Hg}$. Concerning the circadian rhythm, 5 of these children were in the group of dippers, 4 of them in thr group of non-dippers.

\section{Conclusions}

Thus, in children, in which during routine inspection it was found increased blood pressure and / or detect elevated body mass index, there is variability of daily blood pressure monitoring indicators. According to the nowadays studies, that shows that the most important modulator of systemic blood pressure, the violation of which leads to changes in circadian blood pressure profile is the tone of the autonomic nervous system, we can assume that recived daily blood pressure monitoring features related with background imbalance of the autonomic nervous system, which leads to inadequate nocturnal blood pressure reduction. In groups with insufficient and / or excessive nocturnal decrease of blood pressure and increased blood pressure in night there is no adequate night normalization of blood pressure due to the influence of neurohormonal systems which require further study. 


\section{REFERENCE}

1. Ященко, Ю. Б. Динаміка захворюваності та смертності внаслідок хвороб системи кровообігу в Україні (регіональний аспект) / Ю. Б. Ященко, Н. Ю. Кондратюк // Україна. Здоров'я нації. - 2013. - № 1. - С. 20-27.

2. Mitchell, C. K. A simplified table improves the recognition of paediatric hypertension / C. K. Mitchell, J. A. Theriot, J. G. Sayat // J. Paediatr. Child. Health. - 2015. — Vol. 47 (1-2). - P. 22-26.

3. Raj, M. Essential hypertension in adolescents and children: Recent advances in causative mechanisms / M. Raj // Indian. J. Endocrinol. Metab. - 2014. - Vol. 15. - P. 367-373.

4. Chen, $B$. Waist circumference as an indicator of high blood pressure in preschool obese children / B. Chen, H. F. Li // Asia Pac. J. Clin. Nutr. - 2011. - Vol. 20 (4). - P. 557-562.
5. Значення добового моніторингу артеріального тиску у практиці сімейного лікаря. Методичні рекомендації / М. М. Гречко [та ін.] / МОН України, ДВНЗ «Ужгородський національний університет», Інститут післядипломної освіти та доуніверситетської підготовки. - Ужгород, 2013. - 24 с.

6. Поширеність надлишкової маси тіла та підвищеного артеріального тиску серед школярів різних регіонів України / В. Г. Майданник [та ін.] // Междуранродный журнал педиатрии, акушерства и гинекологии. - 2013. - Т. 3, № 1. - С. 33-39.

7. Prevalence of obesity and trends in body mass index among US children and adolescents / C. L.Ogden [et al.] // Pediatrics. - 2012. — C. 483-490.

8. Нечитайло, Ю. М. Перцентильні нормативи фізичного розвитку дітей (Ріст і розвиток дитини: додаток) [навчальний посібник] / За ред. Ю. М. Нечитайла. — Чернівці : БДМУ, 2012. — 24 с.

\title{
УДК 618.2/7-006.52 \\ ОСОБЕННОСТИ ТЕЧЕНИЯ БЕРЕМЕННОСТИ, РОДОВ, ПОСЛЕРОДОВОГО ПЕРИОДА И СОСТОЯНИЕ НОВОРОЖДЕННЫХ У ЖЕНЩИН С ГЕНИТАЛЬНОЙ ПАПИЛЛОМАВИРУСНОЙ ИНФЕКЦИЕЙ
}

\author{
С. С. Кравченко ${ }^{1}$, Т. Н. Захаренкова ${ }^{1}$, О. А. Теслова ${ }^{2}$ \\ ${ }^{1}$ Гомельский государственный медицинский университет \\ ${ }^{2}$ Управление здравоохранения Гомельского об̆лисполкома
}

Цель: выявить особенности течения беременности, родов, послеродового периода и состояния новорожденных у пациенток с генитальной папилломавирусной инфекцией в зависимости от ее формы и вирусной нагрузки, оценить факторы течения гестации и родов в процессе вертикальной передачи и неонатальной персистенции ВПЧ-инфекции.

Материалы и методы. Обследованы 132 беременные пациентки с ВПЧ-инфекцией гениталий, их дети сразу после рождения $(\mathrm{n}=107)$ и в возрасте 6 месяцев $(\mathrm{n}=106)$. Группу сравнения составили беременные пациентки, роженицы и родильницы, которые наблюдались и были родоразрешены в учреждениях здравоохранения Гомельской области в 2011-2012 гг. (30087 беременных, 33477 рожениц).

Pезультаты. Беременность у пациенток с папилломавирусной инфекцией чаще осложнялась угрозой невынашивания $(\mathrm{p}=0,0016)$. Клинические особенности ВПЧ-инфекции не показали влияния на течение беременности. У пациенток с высоким уровнем нагрузки ВПЧ (более $5 \mathrm{lg}$ г.э. на 100000 клеток) в 3 раза чаще роды осложнялись травмами мягких тканей родовых путей $(\mathrm{p}=0,029)$. Беременность, осложненная гестозом и анемией, а также вагинальные роды являлись факторами риска перинатальной передачи ВПЧ. Течение беременности и родов не являлось определяющим фактором при персистенции ВПЧ в организме ребенка.

Заключение. Выявлены особенности течения беременности и родов у женщин с генитальной ВПЧинфекцией (угроза невынашивания, травматизм родовых путей при высокой вирусной нагрузке), факторы перинатальной передачи (гестоз и анемия беременных, роды через естественные родовые пути).

Ключевые слова: вирус папилломы человека, беременность, вертикальная передача.

\section{THE FEATURES OF THE COURSE OF PREGNANCY, DELIVERY, POSTPARTUM PERIOD AND STATE OF NEW-BORNS IN WOMEN WITH GENITAL HPV INFECTION}

\author{
S. S. Kravchenko ${ }^{1}$, T. N. Zakharenkova ${ }^{1}$, O. A. Teslova ${ }^{2}$ \\ ${ }^{1}$ Gomel State Medical University \\ ${ }^{2}$ Department of Health Gomel Oblast Executive Committee
}

Objective: to define the features of the course of pregnancy, delivery, postpartum period and state of newborns in female patients with genital HPV infection, depending on its form and viral load; to assess the factors of the course of gestation and delivery in the vertical transmission of neonatal persistence of HPV infection.

Material and methods. The study involved 132 pregnant women with genital HPV infection, their babies immediately after birth $(n=107)$ and at the age of 6 months $(n=106)$. The comparison group included pregnant patients, women in delivery and postpartum period who were under supervision and who gave childbirth in Gomel region over 2011-2012 (30087 pregnancies, 33477 births).

Results. Pregnancy in women with HPV infection is frequently complicated by the threat of miscarriage $(p=0.0016)$. The clinical manifestations of HPV infection showed no effect on the gestation. Patients with high HPV load (5 lg GE per 100,000 cells) had birth canal injuries $(p=0.029) 3$ times more often. Pregnancy complicated by gestosis and anemia, as well as vaginal childbirth were risk factors for perinatal transmission of HPV. The course of pregnancy and delivery were not determining factors in the persistence of HPV in the baby`s upper airways. 